ægis of the National Union of Scientific Workers is overlooked.

Of this body you say "it is a Trade Union affiliated, we believe, to the Labour Party, and it exists to secure suitable conditions of work and payment for its members rather than for the extension of natural knowledge." In that statement truth and error are intermingled. The National Union of Scientific Workers is a registered Trade Union; it registered as such when industrial and Civil Service joint councils on the Whitley plan were being set up and when it was announced that none but members of Trade Unions would be given representation on those bodies. The Employers' Federations registered as Trade Unions also and for the same reasons. But the National Union of Scientific Workers is not affiliated to the Labour Party or to any political party; it has no political funds, and it imposes no restraints upon the political activities of its members, three of whom stood for Parliament at the recent election, one in the Conservative interest and the other two as Labour candidates.

Again, while it is true that the National Union of Scientific Workers exists to secure suitable conditions of work and payment for its members-and all other scientific workers incidentally-it considers that the best way to do this is by raising the professional standard of scientific workers by improved training and education, and making them aware of their importance as citizens on one hand, and on the other, by pointing out to employers and captains of industry that it is an economy to employ the best scientific workers, to encourage research, and to assist the universities. In order to persuade private employers, corporations and governing bodies to deal justly with scientific staffs, it is true that the Union would be prepared to follow the methods employed by such bodies as the British Medical Association; but it believes with the British Science Guild that the attitude of the general public towards science is due to ignorance or apathy. Accordingly, it puts propaganda efforts, designed to cure these diseases, in the forefront of its programme, hoping thereby to increase the demand from industry and the State for the best scientific knowledge. It is ready to cooperate with any other body for this purpose, and to assist any political party with its advice on matters appertaining to science and scientific workers. It believes, however, that scientific workers themselves must be their own propagandists, and that the first step towards really effective action is unity in the profession of science.

A. G. CHurCh,

National Union of Scientific Workers, General Secretary. 25 Victoria Street,

Westminster, London, S.W.I, December 18

[THE National Union of Scientific Workers is an occupational organisation; therefore its propaganda efforts, useful as they are, are naturally regarded by the public as arising from self-interest. The British Science Guild, on the other hand, requires no technical or other qualification for membership; and, as was pointed out in our article, it bears the same relation to scientific workers that the Navy League does to the Royal Navy. It seems to us that a body of this type, in which citizens engaged in many and diverse departments of national life are concerned, can afford much more effective and disinterested support of science than is possible by any group consisting of members of the profession alone. That was the main point of the article to which Major Church refers, and we see no reason to depart from it.-EDITOR, NATURE.]

\section{The Hermit-crab (E. bernhardus) and the Anemone (C. (Sagartia) parasitica).}

In Nature of December 2, p. 735, I described observations and experiments on the common hermitcrab ( $E$. bernhardus) with its messmates, the anemone (C. (Sagartia) parasitica) and the polychæte worm Nereis fucata. By the kindness of Mr. Hugh Main, it has been pointed out that the observations mentioned above with regard to the natural position of the anemone confirm those of J. Sinel (p. 39, "An Outline of the Natural History of our Shores," I906). Sinel states that " the woodcuts that appear in many text-books-even our high-class oneswhich represent this anemone and its congener, are in one respect incorrect. The anemone is always represented as upright--palm-tree like-on the top of its equipage, as if its chief object were displayor a ride. . . . I have invariably found the anemone affixed to the rear of the shell and in such a position that when the hermit is at a meal or even moving about, the margin of the tentacles just touch the ground, like some patent sweeping-machine. It, no doubt, finds this position a paying one."

Sinel's unique and fascinating book contains a fund of information hidden away in a popular description of natural history on the shore. It is plain that, owing probably to the popular character of the book, many naturalists have passed over important original observations described therein by Sinel, whose knowledge of the biology of the shore has probably never been equalled.

Sinel's observations were previously unknown to me, but the agreement in the two sets of independent observations is valuable in opposing a traditional error, and will be sufficient to establish the correctness of the interpretations ; the natural position of the anemone on the hermit-crab was clearly first shown by Sinel.

Marine Biological Laboratory,

Plymouth, December I3.

\section{Winter Thunderstorms.}

MAY I through your columns again ask for reports of thunderstorms occurring in the British Islands between January I and March 3I ? With the help of your readers and of observers of the British Rainfall Organization I was able to collect a mass of information on winter thunderstorms for I9I6, I9I7, I9I8, and 1920, from which it appears that on more than 40 per cent. of the days in question, thunderstorms occurred somewhere in the British Islands. In collaboration with the Meteorological Office I propose to collect information again. The chief points to be noticed are the times at which the storms occur, and especially the times of passage of such storms as pass overhead; whether a severe storm or whether there are only one or two flashes of lightning or only one or two claps of thunder; whether there is a change of wind or a drop of temperature with the storm; whether there is rain, hail, or snow; in the case of lightning seen at night the direction in which it occurs; and any other information the observer thinks of interest. Reports are wanted especially from the west and north of Scotland, and from the south-west, west, and northwest of Ireland, but any information however slight from any district in the British Islands will be of great use to the investigation. Reports should be sent by postcard or letter to my address (not to the Meteorological Office).

Stoner Hill, Petersfield, December 20. 